\title{
Experiences of Uyghur Migration to Turkey and the United States: Issues of Religion, Law, Society, Residence, and Citizenship
}

\author{
Mettursun Beydulla
}

At least one million Uyghurs now live outside their homeland Xinjiang, also known as the Xinjiang Uyghur Autonomous Region (XUAR) and East Turkistan. The experience of migration has been a reality for many years for these Diaspora Uyghurs. They reside in about 50 different countries around the world, but two locales where Uyghurs reside, Turkey and the Us, will be the focus of this paper. First, I will describe the migrations to Turkey — when, why and how they were treated. Then I will focus on the Us. Following that, I will describe and analyze the differing experiences of the various waves of migrants in light of five topics. The first topic is religion, where I will compare the traditional dichotomy of migration to a Muslim and/or a non-Muslim state, the Dār alIsläm and Där al-Kufr. The second topic will be the issue of law and the implementation of changing laws during the periods of migration. The third topic is society, specifically the integration of migrants into their new home cultures. The fourth is residence, which encompasses both legal and illegal means of staying or residing in a country and how this impacts the fifth topic, citizenship. At every juncture, the relationship with the People's Republic of China (PRC), looms large, affecting integration, legal status, business and political factors that impact the Uyghurs in the Diaspora. In the concluding remarks, I will address the issues of identity and the maintenance of Uyghur culture in the Diaspora and how this has been affected by the factors above.

As well as published sources, I draw heavily upon my own experiences as a Uyghur in the Diaspora and the fieldwork that I pursued between June 2013 and September 2017. This fieldwork was carried out while working as an academic in Istanbul, Turkey and later in the United States. I interviewed 200 Diaspora Uyghurs who resided in Istanbul, Ankara, and Kayseri in Turkey as well as Washington, New York and Boston in the Us. Also interviewed were Uyghurs currently residing in other countries. Questions asked included those about their migration, and specifically how they maintained their Uyghur identity in 
the Diaspora. They were asked about their use of language, religious practices, food, clothing, holiday celebrations, problems they faced and how they and their children identified themselves.

During the fieldwork research in Turkey, I interviewed the well-known Uyghur religious scholars Dr. Atavulla Karakas and Hebibulla Kuseni in Istanbul, exploring their view of immigration and how it can be interpreted from an Islamic perspective. Their views regarding Uyghur migration were located in the hijra as referring exclusively to flight and refuge or seeking asylum. Hijra has more often been used in relation to emigration to join a Muslim community elsewhere to ensure the safe practice of the Muslim faith, meaning for religious reasons. In the Qur'an there is no excuse for suffering under persecution when there are other places to seek refuge. Uyghurs have long been oppressed culturally, economically, socially and religiously. Currently they suffer severe restrictions on the practice of their religion. Because of this, thousands of Uyghurs have been forced to leave their homeland, East Turkistan, to safe places such as Turkey and Western countries. According to Islamic teaching, every part of the earth is Allah's land. Now, borders divide nations and block the flow of migration from one land to another. Yet it does not matter where Uyghurs migrate, as much as their ability to maintain their religious life.

\section{Geography, History and Culture of the Uyghur}

Uyghurs are the indigenous people in Xinjiang. Most of the world's Uyghurs, Turkic-speaking Sunni Muslims who belong to the Hanafi school of law, live in Xinjiang, the biggest province of China. Although the XUAR is home to 13 ethnic nationalities, the largest minority is the Uyghurs (about 11 million, based on official statistics) who make up $45.9 \%$ of the total population of XUAR and about $1 \%$ of the total population of China. Some Uyghur scholars, writers and activists stressed that the total population of Turkic people in Xinjiang such as Uyghur, Kazakhs, Kyrgyz and Uzbek is 25 million, even some of them claim 35 million. Located in the center of the Eurasian continent, the total land mass of Xinjiang is $1,600,000$ square $\mathrm{km}$, making up $1 / 6$ of China. Xinjiang shares international borders with Russia in the north, Kazakhstan in the north-west, Kyrgyzstan, Tajikistan and Afghanistan in the west, and Pakistan and India in the south-west (figure 10.1).

Xinjiang is rich in raw materials and natural resources. Oil reserves in Xinjiang total 23.4 billion tons, and gas reserves are roughly 13 trillion $\mathrm{m}^{3}$ (Jinhui et al. 2016), making Xinjiang one of biggest oil and gas producing 


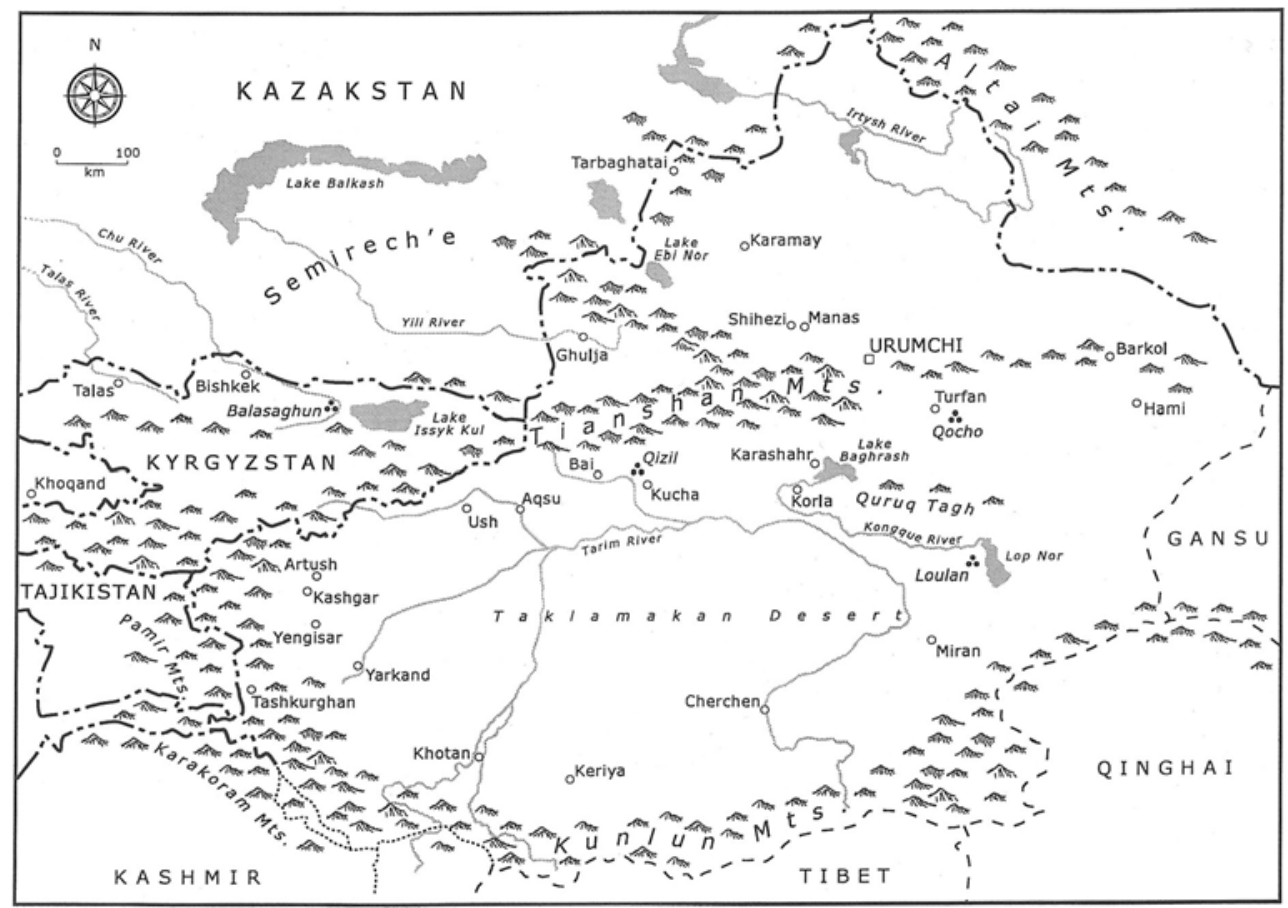

FIGURE 10.1 The Xinjiang Uyghur Autonomous Region

regions in the world. It is also the gateway to the Silk Route, through which China not only exports to Central Asia and the Middle East, but also imports oil and gas for its economic development. Right now, China's major foreign policy initiative is the One Belt and One Road Initiative. Xinjiang is right in the middle, the hub of that infrastructure development plan.

The geographic foundations that constitute the divisions according to culture and ecotype in the north, south and east are the patterns of the dominant landforms of mountains and deserts. North Xinjiang includes the arid steppe grassland of the Jungarian basin, surrounded by mountains and high pastures. East Xinjiang includes the cities of Turfan, and the large oases around it. South Xinjiang consists of the oases surrounding the Tarim basin and the Taklamakan Desert. Known variously as Kashgaria or Altishehir (six cities), this region has a long and complex history of interaction with Iran and the lands to the south. 


\section{Brief History of Uyghur and Xinjiang (from Ancient Times up to Chinese Communist Rule)}

An outline of Uyghur history is essential in understanding modern Uyghur consciousness and identity. Existing before the eighth century, Chinese historians reported them as Hui-he or Hui-hu. At this time, the Uyghur were just one of a number of nomadic tribes, who in 740 A.D, confederated with other nomads, defeated the Second Turkish Khanate, established a Uyghur empire and then dominated the federation. The traditional shamanistic Turkic-speaking Uyghur came increasingly under the influence of Persian Manichaeanism, Buddhism and eventually Nestorian Christianity. In the year 840 A.D., the Kyrgyz destroyed Uyghur power in Mongolia and the Uyghurs split into two major groups. One moved into the Gansu Corridor region and the other took over the oases north and south of the Tianshan Mountains, establishing the Idiqut Buddhist Uyghur Kingdom in Turfan and the Karakhanli Khanate in Kashgar. These migrant Uyghurs, as well as the indigenous people (such as Scythians, Saks, Tokharians, Sogdian, Hun, and Turks who lived in Xinjiang since $2000 \mathrm{BC}$ ) with whom they assimilated, make up the stock of the current Uyghur population.

Most of the Tarim Basin and Jungaria were ruled by Gengiz (Genghis) Khan, his son Chaghatay and his descendants from the early thirteenth to the midfourteenth century, when the Mongol rulers separated from the Ulus of Chaghatay. As a result, Xinjiang was ruled by the Turkic-speaking Mongols until the seventeenth century, when Qalmaq Mongols grabbed control of the northern part of Jungaria. They helped establish the White Mountain Khoja clan's rule of the Kashgar Kingdom (Brose 2007; Light 2008).

The Manchu Qing emperor Qianlong had success against the Muslims in western Xinjiang in 1758 and south of Lake Balkhash in 1795, once and for all bringing the entire area within Chinese rule (Hsü 1995). In 1865 a second attempt at establishing an independent Muslim state in southern Xinjiang was made by a leader from Kokand. Within five years, Yakub Beg ruled over a large area of Xinjiang from his base in Kashgar, uniting Muslims across the entire region. After the defeat of Yakub Beg by Zuo Zong-tang in 1878, the region passed into the hands of a Han dominated administration. It was at this time that the name Xinjiang was given to the region on November 18, 1884. Xinjiang means "new borderlands" or "new frontier." In 1911, the Nationalist Chinese overthrew Manchu rule and established a republic.

The Uyghurs staged several uprisings against the nationalist Chinese rule during this period. Twice, in 1933 (in Kashgar) and 1944-1949 (in Ghulja), the Uyghurs were successful in setting up a short-lived independent Eastern 
Turkistan Republic. The 1759 Qing occupation, the 1879 Zuo Zong-tang reconquest of Xinjiang and those two secular independent East Turkistan Republics are symbols for most Uyghurs of the illegitimate outsider domination and a legitimation for their cause. The mere mention of the term Sherqi Türkistan (Eastern Turkistan), the preferred term of Uyghurs, especially Uyghur nationalists and diasporas, is enough to draw accusations of separatism or even terrorism from the Chinese government.

\section{$4 \quad$ Uyghur under Control of the Peoples Republic of China (1949 to Present)}

Communist China, with the collaboration of the Soviet Union seized Xinjiang in 1949, and the second Eastern Turkistan Republic (ETR) collapsed. The Uyghurs were (yet again) incorporated into China. In October 1955, Xinjiang was officially made the Xinjiang Uyghur Autonomous Region and the Uyghurs were designated as the titular nationality of the region, thus making Xinjiang the homeland of the Uyghur. From 1950 to 1958, the government's mission was to create national unity and establish loyalty among all the minority populations by promoting patriotism and socialist ideology. A tightened control of religion, underpinned by the atheistic principles of Marxism/Leninism, suppressed Islam and ethnic consciousness, alternated with periods of more lenient policies. The Great Leap Forward (1958-62) and the Cultural Revolution $(1966-76)$ were two periods of the greatest intolerance. Many religious holy places including mosques were destroyed or changed into warehouses or pigsties. Intellectuals or secular nationalists who played a role in the clergy were labeled "counter revolutionary." Many members of the clergy such as sheikhs and ishans (religious clerics), or believers suspected of disloyalty, were persecuted, sent to re-education camps, or executed.

The end of the Cultural Revolution ushered an era of reform policies characterized by an expansion of the school system, a drop in illiteracy, and an official softening towards religion and the use of minority languages in education. There were more opportunities for education and a moderate return of religious practices. Churches, mosques, and temples began to reopen in the years following official reauthorization in December 1978. The decade of 1980 to 1990 saw a progressive opening of borders that made Uyghur youth better able to travel more freely and provided opportunities for spiritual exchange and revival. Until the mid-199os, hundreds of young Uyghurs attended religious schools in Pakistan, Egypt, Turkey, and Saudi Arabia, and a few of them also headed to Yemen, Qatar, and Malaysia for the same reason. 
During this period, hundreds of Uyghur immigrated to Central Asia, North America, Europe, and especially to Turkey. Domestic (1989 Tiananmen protest) and international (collapse of the Soviet Union) events made the Chinese government change their policy toward Uyghurs. Policy changes that date from 1989/1990 include changes in religious tolerance, which were mirrored in a crackdown on religious education. Attitudes towards Uyghurs involved reforms or reinterpretations of official policies towards religion, education, and cultural expression. The government began to issue licenses for legal mosques, reviewed appointments of imams and started an "education in atheism" campaign (Amnesty International 2002). Thus began a Sinicization by educating Uyghurs into Chinese culture. Legally, neither the Qur'an nor religion could be taught to students younger than eighteen. Chinese schools and television reinforced this Sinicization by teaching "patriotism" at the expense of other cultural expressions. Restrictions also included banning religious practices during Ramadan, increasing control over Islamic clergy, and the detention or arrest of religious leaders who had been labeled "hypocrite," "unpatriotic" or "subversive" (Human Rights Watch 2005). Restrictions included the annual pilgrimage to Mecca. "In contemporary Xinjiang, the power of the state to regulate religion, including Islam, has brought the forces of law and order into direct conflict with Muslims who are trying to live according the tenets of their faith" (Fuller and Lipman 2004, 323). Since September 2017, Chinese officials have confiscated religious items including prayer mats and copies of the Qur'an in Xinjiang. These copies were taken as part of a Xinjiang-wide campaign that bans "illegal" publicity materials, religious activities and religious teachings that officials consider to be tools of terrorism (Radio Free Asia 2017b).

Education is the key to Sinicization. In order to speed up assimilation, in 1997, the government provided a new model for compulsory Chinese language education and the marginalization of the Uyghur language as well as other minority languages in Xinjiang. By using the term bilingual education, the government is implementing a monolingual language education system that undermines the linguistic basis of Uyghur culture. Chinese has become the only official language and is now the language of instruction in all levels of Uyghur schools including kindergarten (Dwyer 2005). The government has exerted more and more control over every aspect of life in Xinjiang. Now, Uyghurs have become strangers in their own land. (Bovingdon 2010). China bans the Uyghur language in schools in Hotan (Radio Free Asia 2017a), as well as other places.

Ethnic tensions have clearly increased in Xinjiang, especially since the 2009 Urumqi riot and that worries Chinese government officials. As a result of Chinese repressive policies, Xinjiang has become the largest outdoor prison in the 
world. (Xiang, 2019). In August, 2018, a United Nations panel reported that China had turned Xinjiang into "a massive internment camp." United Nations human rights experts have expressed alarm at what they said were many credible reports that China had detained a million or more ethnic Uyghurs in the western region of "Xinjiang" and forced as many as two million to submit to re-education and indoctrination. Gay McDougall, a member of the UN Committee on the Elimination of Racial Discrimination has described this as, "something resembling a massive internment camp, shrouded in secrecy, a sort of no-rights zone," (Cumming-Bruce, 2018). The government has intensified the crackdown on Uyghurs inside Xinjiang with increased pressure on Uyghurs outside Xinjiang. For example, the Chinese government has forced thousands of Uyghur students abroad to return home since January 2017. Under pressure from the Chinese government, the Egyptian government arrested hundreds of Uyghur students in July 2017 (Aljazeera News, 2017). Some of them are still in jail, some have been released and some repatriated to China. Hundreds of Uyghur students fled to Turkey and a few to Europe.

\section{The Uyghur Diaspora in Turkey}

After the PLA (Peoples Liberation Army) entered Xinjiang in 1949, a number of Uyghur leaders managed to escape, finally settling in Turkey. Since then, the migration has continued in waves. At first, they fled China to neighboring countries, mainly to India (Kashmir), Pakistan and Afghanistan, but also to Kyrgyzstan and Kazakhstan. While most of them stayed, in the second stage many Uyghur refugees left their host country and re-migrated to a second host country, usually for economic reasons but also, as in the case of Turkey, for cultural and political reasons. In the third stage, Uyghurs migrated yet again, from a second host country to a third host country-Australia, Western Europe and North America-primarily for economic, but also for political reasons.

In this migration process, Turkey became a terminal destination as well as a transit or junction to other destinations. Of the one million Uyghurs who make up the Uyghur diaspora, the largest concentration outside Xinjiang can be found in the "West Turkestan" central Asian states of Kazakhstan, Kyrgyzstan, Turkmenistan and Uzbekistan, as well as significant clusters in Pakistan and Afghanistan (Chung 2002; Wang 2003). The largest Uyghur population resides in Kazakhstan, where 300,000 have lived for several generations (Golovnina 2009; Leonard 2009). After Central Asia, the next largest diaspora community resides in Turkey, where Uyghurs claim ancestral links to the Turks. Because of Turkey's ancestral, historical, linguistic and cultural ties, it has been the most 
attractive destination for Uyghurs looking to escape the influence of Communism. As a result, Turkey has been the most influential node in the Uyghur diaspora during the twentieth century. This may also explain why Turkey, since the 195os, has provided Uyghur activists a primary haven to help shape an East Turkestan independence movement (Shichor 2007). Of the total population of Uyghur living in Turkey, estimated to be 35,000-45,000 about 10,000 of them are refugees.

Already in the nineteenth century Turkey served as a model for Turkistan nationalism. Although Turkey could not extend its assistance to Xinjiang's Turkic nationalities, they have always regarded Turkey as a model and a source of moral support and ideological inspiration. Indeed, following the flight of Uyghur refugees from Chinese Communism in March 1952, Turkey, supported by the United Nation High Commissioner for Refugees (UNHCR), offered sanctuary (in fact, political asylum) to 2,00o Eastern Turkistan refugees who had fled Xinjiang to India and Pakistan following the communist occupation. In 1953, Turkey accepted an additional goo Eastern Turkistan refugees from Kashmir and Pakistan. This Turkish policy, offering temporary or permanent residence, persists to this day. In 1965, Turkey accepted 235 from Yarkand, one third of a group of Uyghur refugees who had fled to Afghanistan in 1961. Their absorption was made possible by a special resettlement program financed by UNHCR, at the request of the Turkish government. Like their predecessors, they were given citizenship and provided with housing. Uyghur have continued to arrive in Turkey since the late 196os, mostly on an individual basis. Since the 1980s Open Door policy, many Uyghurs have left China to study abroad or go on pilgrimage (hajj) to Mecca, never to return. In August 1982, Turkey accepted another group of several thousand Uyghur refugees who had come from Afghanistan and Pakistan. Many of them had escaped from Xinjiang by crossing the border, now more open and less guarded.

Thus, the Turkish experience created two groups of Uyghurs, called "yerlik" (local) or "kona" (old) who were descendants of those migrating at earlier times, and "yengi kelgenler" (newcomers), those immigrants since 1980. At first the cultural differences between these groups were significant. The "yerlik" were more Turkicized, more religious and looked down upon the newcomers because of their ignorance of religion. The newcomers, those who arrived since 1980, have more relational ties with the Uyghurs of Xinjiang. Most newcomers saw their new life in Turkey as a temporary solution to the political and economic turmoil transpiring in their "homeland." They felt they would be able to return and reclaim their "homeland" once the Chinese communists left Xinjiang or the regime changed. 
Isa Yusup Alptekin and Mehmet Emint Bugra, who, after spending a few years in Kashmir following their flight from Xinjiang, had finally settled in Istanbul, led the Uyghur community in Turkey. After Bugra's death in 1965 , Alptekin remained the uncrowned leader of Eastern Turkistan until his death in 1995, aged 94. Their activities had always been aimed at two interconnected targets and at two different audiences simultaneously. Alptekin was particularly active in raising awareness for the Uyghur causes and paid visits to many organizations such as the Muslim World League and the Arab League as well as attending the Bandung Conference in 1955, the Afro-Asian Conference in 1965 and the World Congress of Islam in 1964 (Landau 1995, 118, 150; Shichor 2003, 290). The Uyghur diaspora community in Turkey has also worked closely with the Turkish government, and in return, Turkey remains highly critical of Beijing's Xinjiang policy and is sympathetic toward the plight of the Uyghurs. In the 198 os and since, especially since 2009 , there has been a new wave of migration that crossed the international borders in order to visit relatives, engage in trade, to study and for many, to flee from Chinese persecution. Initially, most Uyghur migrants who had arrived tended to settle together, creating special quarters such as Zeytinburnu, Sefakoy, Aksaray, Kaya Sehir, and Selim Pasa in Istanbul or Yasevi in Kayseri. There, residential concentrations can also provide networking opportunities for new immigrants. Those with professional skills have many opportunities in Turkish society, but Uyghurs who do not have qualifications are often trapped in specific labour markets. Occupation plays an important role in shaping identity and giving a sense of difference. One's identity may limit or increase not only one's employment opportunities but also one's social integration.

The interaction between the various communities of Uyghurs has helped shape the current concept of a common Uyghur identity. A sense of a unique community has begun to dissolve as the younger generations have become Turkicized and lost their Uyghur cultural and linguistic identity. They have tended to leave their traditional communities seeking accommodation, education and employment. For similar economic and professional reasons, since the 196os, many of Turkey's Uyghurs began immigrating to third countries, such as Canada, Holland, and Scandinavia, but primarily to Germany. Paradoxically, it has been more difficult for them to assimilate and easier to maintain their identity in these countries compared to Turkey. Germany has become the central outpost and the most important base for promoting the cause of East Turkistan independence and Uyghur nationalism. Some of the factors are related to the collapse of the Soviet Union in 1991. The independence of the Central Asian countries, with whom Uyghurs share a common religion, culture, language and history, created hopes among Uyghurs and contributed to 
their seeking of a greater autonomy or even independence from the PRC. China, since the 199os, has pressured the Turkish government to restrict Uyghur national activism as it has become more sensitive to separatist activity within its borders. This, combined with growing economic relations between the two countries, has dampened Turkey's enthusiasm in hosting the Uyghur community (Shichor 2007). Pro-Uyghur, pro-independence and anti-Chinese government mobilization in Turkey has attracted the attention of Chinese authorities, and this attention has in turn affected and shaped this mobilization.

Since 2009, especially after 2017, China intensified persecution of Uyghurs leading to human rights abuses in Xinjiang. Shortly after the mass arrest of Uyghur students in Egypt and hundreds of arrests and imprisonment in Turkey, Uyghur groups felt the need to move westward again, this time to Europe and eventually the United States. All these developments, along with changes in communications, contributed to a renewed phase of Uyghur diaspora activism. Diaspora members can now share information about news and events and coordinate more easily (Brinkerhoff 2006, 31-32, Bernal 2006, 163). According to Bernal, the internet is a transnational space where diaspora members "produce and debate narratives of history, culture, democracy and identity" (Bernal 2006, 161). Thus, the internet has had the capacity to transform the diaspora.

During the 1990s, many Uyghurs migrated to the United States. Some of them came as students, visiting fellows/researchers and recently came as tourists and later sought asylum. Many of them came as political refugees, fearing prolonged and ruthless Chinese suppression. The Uyghurs from Turkey and the Central Asian region also fled to safer countries like the United States. Many Uyghurs in the us have ensconced themselves in middle class America and are one of the most educated immigrant groups in the us. Those with limited linguistic and professional skills usually work in lower-class, low-wage jobs in restaurants, grocery stores, delivery services, drive taxis or work for Uber. The majority of Uyghur immigrants are first generation foreign-born and came as young singles. Currently, they number around 5,000 to 6,000 and growing. They are mostly concentrated in metropolitan areas such as Washington D.C., New York, Boston, Los Angeles and San Francisco. First-generation Uyghur Americans prefer to live in a Uyghur neighborhood because of language difficulties. For many unskilled Uyghur immigrant workers, staying in the same neighborhood with fellow Uyghurs can provide important advantages for 
better survival in the "strange land." Relatives or friends who already live in the area may provide them with places to stay and work, thus speeding up the process of acculturation.

The Uyghur immigrants in the us have remained attached to their culture, which finds expression in the traditional festivals, ceremonies and socio-cultural activities. They remember the two East Turkistan Republic foundation days, several incidents such as the 1990 Barin incidents, the 1997 Ghulja demonstration and the 2009 Urumqi riot (Millward 2009). These are seen as protests to the Chinese government, where Uyghurs were cruelly suppressed, hundreds were killed, thousands injured and scores of people were disappeared after each event. They also celebrate New Year and religious holidays like Ramadan and Qurban Eid and organize a couple of protests in front of the Chinese embassy in Washington each year. They engage in traditional Uyghur dance theatre, drama, stage shows, and organize picnics and prayers. These activities are organized by the Uyghur American Association and the Uyghur Human Rights Project in Washington DC., who work along with the World Uyghur Congress.

\section{Issues and Factors of Religion, Law, Society, Residence and Citizenship}

\subsection{Turkey}

As has been mentioned above, Turkey hosts Uyghur separatist activists and human rights organizations. Since the mid-199os, Beijing has been applying pressure on Ankara to curb Uyghur separatist activism in Turkey. Beijing has used its relations with the Kurds, who claim Turkish territory, to twist Ankara's arm (Kuang Shengyan 1995). Beijing has used an analogy between Uyghurs and Kurds, saying that if Ankara continues to support Uyghurs, Beijing will support Kurds. When President Jiang Zemin visited Turkey in April 200o, he indicated that both countries were faced with the task of protecting national unity and territorial integrity and both opposed all kinds of international terrorism, national separatism and religious extremism ( $\mathrm{Si}, 2000)$.

These days, Turkey hosts thousands of Uyghur refugees and immigrants, but their situations are precarious. Aside from those who are citizens, many do not have legal or social protection and live on the charity of Turkish people (zakat). In pursuit of work and residence permits, they have to deal with various authorities. Many live in constant insecurity, stress and fear, and are forced to remain in such a state of limbo for years. Ethnic tensions have clearly increased in Xinjiang and this worries Chinese government officials. The Uyghurs (40\%), 
Kazakhs, Kyrgyz and other Turkic groups (15\%), who currently make up $55 \%$ of the population in Xinjiang, are closer culturally and linguistically to Turkish people than they are to the Han Chinese. Beijing has planned to combine its intensified crackdown of Uyghurs inside Xinjiang with increased pressure on them outside Xinjiang, through the Turkish government.

In an interview, one of my informants touched on many of these factors at the nexus of law, society, residence and citizenship. He said:

The Chinese government and investors have an interest in Turkey and they have been providing technology and expertise for the development of Turkey and they are promising more. One of my friends, who works for a Turkish company as a translator, told me that $\$ 40-50$ billion deals (joint funds) have already been made or are being discussed. When the Turkish foreign minister visited Beijing this summer he promised to restrict all pro-Uyghur activity in Turkey. At the same time, a number of Uyghur religious leaders, activists and public figures such as Adukadir Yapchan, Canadian citizen Ibrahim Haji, and about a thousand Uyghur refugees were arrested and they are in jail now. I do strongly believe that Turkey is under pressure from the Chinese government. As Turkey receives more economic and technologic assistance from China, there will be more pressure on Uyghurs in Turkey. These is no such thing as a free lunch... I was kicked out in my last year of medical school in Xinjiang, because of my peaceful pro-Uyghur activity. Later, I was able to manage to flee from further Chinese persecution in 2000 and I came to Turkey. I found a safe haven here in Turkey. I went to medical school in Turkey and I earned my degree. Then I worked for a government family care center for the last 10 years. I also married and am raising two children in Turkey. But now I am nervous and do not feel safe anymore here in Turkey. Especially, I don't see a bright future for my children. So first I planned to immigrate to the us or Canada, but based on my knowledge, the us and Canada do not accept my medical degree and experiences. It means an extremely difficult time for me to find a job there. Later, I learned that it will be easy for me to adjust and settle in Europe, especially Germany because I can certify my degree and experiences easily and in a short time. After all, my family and I decided to immigrate to Germany and we have already started the paper work." (Personal communication, September 4,2017$)^{1}$

1 This informant became a Turkish citizen in 2009, his two children were born as Turkish citizens and his wife is an ethnic Uyghur with Chinese citizenship. She applied for Turkish 
On September 25, 2017, Abdulkadir Tumturuk (Deputy Director of the Uyghur association in Kayseri, Turkey) expressed in social media (WhatsApp) that 125 Uyghurs had been released from jail and the Uyghur scholar and activist Abduwali Ayup (exiled in Turkey for the last two years) expressed in a Facebook post that "37o Uyghur are jailed in Turkey, because of terror suspect." Unofficially, yet quite obviously, China's strategy in Turkey is aimed at gaining political influence, security guarantees, economic presence and natural resources as China has wanted to become one of the main economic powers in Turkey. China's strategy and foreign policy in Turkey is firstly determined by its need to consolidate control of "Xinjiang" and restrain the Uyghur independence movement in Turkey. Next in importance is China's trade and economic investments in Turkey, especially its "One Belt, One Road" initiatives. These are not just increasing its influence; they are making Turkey far more reticent to speak out about Beijing's abuses and oppression in Xinjiang. (Gunes, 2019). China's geoeconomic strategy has resulted in political influence in Turkey that profoundly affects its Uyghur population.

\subsection{The United States}

Religion is the main difference between Turkey and the us for Uyghur immigrants. Turkey is a predominantly Muslim country, and the Us, a secular country (but mostly Christian). This obviously colors much of the reception by the local population. Many Uyghurs find themselves socially and legally marginalized by United States' restrictive asylum policies. They cannot lead an independent life or plan a future and they are severely restricted in their settlement, movement, employment and educational opportunities. In pursuit of work and residence permits, they have to deal with various public authorities. Thus, many live in constant insecurity, stress and fear, and are forced to remain so for years, with the threat of expulsion hanging over their heads. In such a situation, it is nearly impossible to establish a home in United states and develop a sense of national belonging.

In a study of attitudes towards immigrants in America, Canada and Europe over the past two decades, Hainmueller and Hopkins looked at two approaches, one of political economy and the other of a socio-psychological orientation. Political economy approaches are characterized as follows: "Frequently starting from formal models of immigration's economic impacts, this theoretical approach explains immigration attitudes with reference to native-born

citizenship in 2016, but she has not yet received any response. He and his family finally immigrated to the UK on March 25, 2019 and are now living in London (Personal communication, March 27, 2019). 
citizens' individual self-interest" (Hainmueller et al. 2014, 2). By contrast, socio-psychological inquiries frequently look at cultural responses based on perceived threats to national identity or prejudices generated by local group contact. The research shows that a country's regime policies have important implications for the populations' intolerance of immigrants. In the US, that has translated into legal and cultural concepts of citizenship, and the general attitude towards immigrants has also become more negative especially since the Trump administration. us President Trump has already cut refugee admissions by more than half, from more than 100,000 down to 50 ,000. In fact, just 22,491 refugees were resettled in the Us in fiscal year 2018, roughly half the 45, 0oo cap. The number of Muslim refugees is down by 9o percent since fiscal year 2017. Drastic budget cuts and staff layoffs began in 2018 and are expected to continue through 2019. Secretary of State Mike Pompeo announced in September, 2018 that the us would admit no more than 30,000 refugees in fiscal year 2019; he also said the lower refugee ceiling would help improve national security (Amos, 2018).

However, others have disagreed. Writer, the us homeland security secretary from 2005-2009, proposed that, "Cutting refugee admission hurts Americans and this would be a mistake. Cutting refugee admission would not only be a moral failure but also damage our national interest abroad and our economy" (Chertoff, 2017).

Uyghurs acquiring Turkish or us citizenship cannot be taken as an indication of a loosening ties to their homeland, East Turkistan. There are two main reasons why Uyghurs distinguish between citizenship and national identity. The first is that permanent and inborn identities and belongings are considered more important than those acquired. A second major reason for the nonidentification with the us nation is the strong belief that "natives" will never perceive naturalized Uyghurs as being American and continue to identify them as "others," because of, according to Uyghurs, their different physical appearance, religion and culture. These two reasons are likely to reinforce one another. Several scholars (Barnes 2001, 410; Kumar Behera 1999, 76; Valtonen 1998) suggest that the experience of social exclusion from the mainstream society is likely to cause ethnic revitalization and a withdrawal of social and emotional commitment to the host society.

Meeting America, as some of my respondents express it, has often been the first meeting with a democratic system and with political freedom. Meeting America has also meant meeting other Uyghur and the Uyghur movement's organizations and institutions. It has also meant opportunities to meet the larger world, intensified interactions, identifications as well as differentiations. All of my informants appreciated American society very much for the political 
freedom that they experienced. They also appreciated the possibilities and perquisites that society allows them as citizens. However, in the Us, they also face racism, otherness and an inferior identity as immigrants. A number of informants encountered overt racism and many believe they have fewer chances of finding employment and housing. Some informants stressed that at work and when they apply for jobs, they experienced disrespect, humiliations, rejections and blocked opportunities. A number also complained about the United States banking system. They stressed that in the United States there is no governmental encouragement for citizens to help immigrants. The us banking system is based on personal credit history. If an immigrant does not have a good history, he cannot get a loan. It takes a long time to develop a credit history and, consequently, this makes the lives of immigrants miserable. As well, visual religious differences, such as the Muslim headscarf, can also greatly influence employment opportunities for immigrant communities. Since 9/11, some Uyghur women have faced discrimination when they apply for jobs. The feeling of marginalization is probably strengthened by the fact that many refugees used to belong to the better-off and educated sections of their country of origin. Some respondents believe that foreigners have to work much harder and prove themselves more in order to reach the same level as Americans. Feelings of not belonging and being different seem to have increased since 2001 and especially since the current administration.

Men tend to have more contact with formal religious structures and other Muslims both in Turkey and the us than women, especially older women, since they attend mosques with greater frequency and work outside the home. Islam may well offer both a structure within which they can find meaning and purpose in their lives, and certain rights and privileges in private life that they do not have in public life. Some young women in Turkey and U.S have chosen to adopt the hijab, or more "orthodox" veil, which they would not have worn in Xinjiang. This is seen as similarly empowering, in that it allows them to project the importance of their identity as Muslims and enables them to honour Islamic morality while moving in non-sex-segregated and non-Muslim spaces.

Differences between the generations are undoubtedly exacerbated in the Us because the younger generation moves with greater ease in the "foreign" land. They are generally more proficient in English than their parents, and they sometimes act as translators when their parents have to deal with us institutions. They have gone to school and spent more of their formative years in the us than their parents. Some of them have non-Uyghur friends (as their parents are less likely to), and they are more familiar with technology.

Even those Uyghurs who are not particularly religious, though, still insist on the importance of marrying Muslims. For men, and less so for women, 
marriages are sometimes arranged with Uyghurs outside of the us and occasionally young Uyghur men marry outside the group. Still, there is considerable pressure to marry within the community or, at least, to marry another Muslim. The most important consideration, perhaps, is the Uyghur fear of losing their identity as Muslims, usually expressed as the fear of raising children who are "confused" by conflicting religious messages or fear of their children becoming "käfir" (unbelievers). Many Uyghurs said that they believe they will be judged guilty and will be punished on judgment day for their children's "deviant" behavior and "sins."

\section{Searching for Identity among the Uyghur Diaspora in Turkey and the United States}

Uyghur identity-construction spaces are those in which Uyghurness is formed, celebrated, and promoted and in which the values of the community are transmitted to the next generations. Uyghur spaces can be seen in five categories: cultural, labour/market, residential, institutional, and organizational/political spaces. These spaces are not independent of one another, for they all function in an interrelated manner to preserve Uyghur identities and to increase the power of the Uyghur community in the sociopolitical space. The diversity of Uyghur institutions (especially in Turkey) and locations reflects the diversity of the community. Although mosques, for example, are important sites for conservative Muslims, strict seculars distance themselves from such institutions and form their own organizations. Therefore, religion is not only an important boundary between Uyghur immigrants in Turkey and the U.S (and the larger American culture as well), but also a significant boundary within the Uyghur community

Many Uyghurs are very critical about the images of Muslims and of Islam portrayed in the media in the aftermath of $9 / 11$. As non-Western immigrants, they are particularly exposed to discrimination and exclusion in American society. Besides these problems, the category of forced migrants and exiles suffer the traumatic experience of having no access to the places to which they are emotionally and socially related. My informants viewed their Uyghur identity as inborn and inescapable. This biological inheritance through blood and genes must, however, be accompanied with cultural inheritance.

Immigrants are to a large extent pushed back into their own communities and therefore do not always have the same relationship towards the "outside." As the "first generation" they have memories, lived experiences, and connections with a place to which they can relate when they are excluded from the 
receiving societies, while the "second generation" do not always have these in the same way. We are located not only in ethnic categories but also in other intersectional categories such as gender, class, generation, lifestyle, origin, history, nationality, culture, education, sexuality, politics, etc. Uyghur social institutions include schools, mosques, associations, Uyghur restaurants (both in Turkey and the us), social media such as Facebook, WeChat and WhatsApp. They function as identity-construction spaces because they provide sites for Uyghur's distinct experiences and expressions of identity. They help Uyghurs find a special place in the larger Turkish or American space. These institutions represent the Uyghur to "others" and ensure that their voices are heard. Worship places, churches, synagogues, and mosques, serve as sacred spaces where meanings, ethics, and values of a particular nation or culture are transmitted through religious discourse and interaction (Barot 1993). As spaces of gathering, sharing, and interacting, they also function to preserve identities and produce a community based on religion and nationality (Ernst 1987). Places of worship provide boundaries of difference to resist the dominant culture and celebrate cultural uniqueness. They are territories where a certain degree of autonomy is practiced (Barot 1993).

Due to the importance of cultural practices and memories in conceptions of Uyghurness, Uyghurs are afraid that their "natural" identity as Uyghur will fade away if they do not do the things that make them Uyghur and do not remember "where they came from." Children, and young Uyghurs in particular, are considered susceptible to change due to their lack of memories of Uyghur society. Their exposure to different values and lifestyles has resulted in the older generation not considering them to be "real" Uyghur and they themselves often struggle to define their identity. In their new environment, they begin a process of being forced to revalue and negotiate their sense of themselves, their experiences and knowledge, in order to orientate themselves and find continuity in their identity.

Claims of roots play an important role among the diaspora, but they are weakened by the recognition that roots also have had an influence on their identity, culture and attachment to territory. Paradoxically, it was these experiences of change, displacement and uncertainties about identity themselves that generated the longing to cling to an anchor of roots in the first place.

For diasporic Uyghurs, their identity is formed in direct contact and contrast to non-Uyghurs. Practices and beliefs that used to be simply a part of life have become conscious symbols of Uyghurness, even if these have had to be moderated and adapted to the new environment. To be a Uyghur means belonging to a family that has been broken up and scattered all over the world. It 
means having been displaced from one place to another, and having memories of childhood, landscapes, loss and flight.

\section{9 \\ Conclusion}

The aim of this study was to explore the experience of Uyghur immigration to Turkey and the U.S, in relation to issues of religion, law, society, residence, and citizenship. Their experience in Turkey and the us provides a cogent example of the complex and contested geographies of home and identity and the multiple experiences of displacement. Uyghurs, as refugees, migrants, residents and citizens and in liberal Western democracies, have obtained the possibility to enjoy general human rights and citizen rights, although in different degrees in different countries. In spite of the diversities and differences that divide the Uyghur diasporic community, the Uyghur refugees' relation to Turkey and the us can be analyzed within a context where they all encounter Turkish and us multiculturalism - which implies on the one hand democracy and tolerance, and on the other hand exclusion, inferiority and otherness. Diaspora Uyghurs, especially those living in Turkey (depending on government restrictions), the us and Europe, have played a major role by their contribution to the development of the Uyghur cause by maintaining language and identity. Many significant Uyghur cultural and political activities, which do not take place in "Xinjiang," have found a home in exile.

Global migration is an irreversible historical process and is also a component of the contemporary global system. However, it challenges the concept of citizenship and belonging and demands for adapting to new global conditions. Global migration has become an issue of security and is highly political. The politics of Turkey and the us are gradually changing in order to encompass this shift. Hall claims that a growing number of people "are beginning to think of themselves, of their identities and their relationship to culture and to place, in more "open" ways" (Hall 1995, 207). I consider it incorrect to focus solely on roots and hybridity, because such concepts do not reflect the way that ordinary people and nation states themselves think and speak about identity, culture and place. A few decades of globalization have not led to the development of cosmopolitan hybrids and a post-national world of limitless mobility, but rather to the reinvention of nationalism, boundaries and distinct identities. Immigrants are not viewed or treated as equals by the host society. Hence, there is a gap between formal and "substantive" citizenship. The social relations between refugees or migrants and the rest of society are determined by the position of the immigrant "Other" within the global distribution of power and dominance. 
My research has indicated that ideas about an inborn and unchangeable identity connected to a certain territory and culture remain very much alive among both Uyghur-Turks and Uyghur-Americans. When Uyghurs use language about their roots, they refer to a culture that is in their blood, a connection to East Turkistan's holy soil, and they compare East Turkistan with a nurturing mother figure. When I speak of roots, I do not mean to say that these are naturally and primordially given. Ideas of roots rest upon inventions and imaginations. It is important to realize, however, that they appear to be natural and authentic in the minds of people. The first generation of Uyghur diaspora in Turkey and the us and adults of a young diaspora community are still very affected by the Uyghur movement and politics. They have experiences of, as well as existing and intense social and emotional bonds to, their "homeland" and the Uyghur diaspora community. As the "first generation," they encountered much greater difficulties and obstacles in becoming a part of Turkish and Us society.

Classifying Uyghurs on the basis of national origin as East Turkistan or Uyghur reveals nothing about the actual relationships Uyghurs form on the ground, where shared language, culture, and especially religion is key, while shared national origin is a reminder of historical opposition and persecution. In the multicultural landscape of the Us, Islam offers a means through which Uyghurs can establish themselves in a larger, community of Muslim Americans. It is an identity that seeks to assert its independence from forces abroad, one that combines the essential elements of Islam and the values of American constitutional democracy.

\section{Acknowledgements}

I very much appreciate the efforts of Dr. Ray Jureidini and the CILE team for organizing the CILE Migration Seminar and for their invitation. I also would like to say thanks to Dr. Ray Jureidini; Dr. Said Hassan and Dr. Wachob for their helpful comments and the editing of this article.

\section{Bibliography}

Amos, Deborah. 2018. "2018 Was A Year of Drastic Cuts to U.S. Refugee Admission." NPR, December 27. Available at: <https://www.npr.org/2018/12/27/680308538/2018was-a-year-of-drastic-cuts-to-u-s-refugee-admissions > . 
Aljazeera News. 2017. "Egypt arrests Chinese Muslim students amid police sweep." July 7. Available at: <http://www.aljazeera.com/news/2017/o7/fear-panic-egypt-arrestschinese-uighur-students-170707051922204.html>.

Amnesty International (2002). Peoples Republic of China's Anti terrorism Legislation and Repression in the Xinjiang Uighur Autonomous Region.

Barnes, Diane. 2001. "Resettled Refugees" Attachment to their Original and Subsequent Homelands: Long-Term Vietnamese Refugees in Australia." Journal of Refugee Studies 14(4): 394-411.

Barot, Rohit. 1993. Religion and Ethnicity: Minorities and Social Change in the Metropolis. Kampen, Netherlands: Kok Pharos Publishing House.

Bernal, Victoria. 2006. "Diaspora, Cyberspace and Political Imagination: the Eritrean Diaspora Online." Global Networks 6(2): 161-179.

Bovingdon, Gardner. 2010. The Uyghurs: Strangers in Their Own Land. New York: Columbia University Press.

Brinkerhoff, Jennifer M. 2006. "Digital Diasporas and Conflict Prevention: The Case of Somalinet.com." Review of International Studies 32: 25-47.

Brose, Michael C. 2007. Subjects and Masters: Uyghurs in the Mongol Empire. Center for East Asian Studies, Western Washington University.

Chertoff, Michael. 2017. "How Cutting Refugee Admissions Hurts America." Washington Post, September 15. Available at: <https://www.washingtonpost.com/opinions/cut ting-refugee-admissions-hurts-americans-heres-how/2017/og/14/c7c8b5e6-9987-11e7b569-336oo11663b4_story.html?utm_term=.442ed6o581ac >.

Chung, Chien-Peng. 2002. "China's 'War on Terror': September 11 and Uighur Separatism." Foreign Affairs 81(4): 8-12.

Cumming-Bruce, Nick. 2018. "UN Panel Confronts China Over Reports that It Holds a Million Uighurs in Camps." New York Times. Available at: <https://www.nytimes. com/2018/o8/10/world/asia/china-xinjiang-un-uighurs.html >.

Dwyer, Arienne M. 2005. “The Xinjiang Conflict: Uyghur Identity, Language Policy, and Political Discourse." Policy Studies 15. Available at: <http://www.eastwestcenter.org/ fileadmin/stored/pdfs//PSo15.pdf $>$.

Ernst, Eldon G. 1987. Without Help or Hindrance: Religious Identity in American Culture. 2nd ed. Lanham, Md.: University Press of America.

Fuller, Graham E and Jonathan N. Lipman. 2004. "Islam in Xinjiang." In Xinjiang, China Muslim Borderland, edited by S. Fredrick Starr, 320-352. Armonk, NY: M.E. Sharpe.

Gernet, Jacques. 1982. A History of Chinese Civilization. Cambridge: Cambridge University Press.

Golovnina, Maria. 2009. "Asia Uighurs Harbour Revenge for Xinjiang Kinfolk." Reuters, 16 July. 
Gunes, Gokan. 2019. “Turkey Treads Tricky Path with China's Muslim Minorities.” AfP News, March 21. Available at: <https://sg.news.yahoo.com/turkey-treads-trickypath-chinas-muslim-minorities-032439406.html>.

Hainmueller, Jens and Daniel J. Hopkins. Public Attitudes Toward Immigration. Centre for Research and Analysis of Migration. Department of Economics, University College London. Available at: <http://cream-migration.org/publ_uploads/CDP_15_ 13.pdf $>$.

Hall, Stuart. 1995. "New Cultures for Old." In A Place in the World? Places, Culture and Globalization, edited by Massey, Doreen and Jess, Pat: 175-211. Oxford: Open University / Oxford University Press.

Hsü, Immanuel C.Y. 1995. The Rise of Modern China Fifth Edition. New York: Oxford University Press.

Human Rights Watch. 2005. "China: Religious Repression of Uighur Muslims.” Available at: <http://www.hrw.org/en/news/2005/o4/10/china-religious-repression-uighurmuslims $>$.

Jinhui Duan, Shuying Wei, Ming Zeng, and Yanfang Ju. 2016. "The Energy Industry in Xinjiang, China: Potential, Problems, and Solutions. Power." Available at: <http:// www.powermag.com/energy-industry-xinjiang-china-potential-problems-solutionsweb $>$.

Kuang, Shengyan and Zhihong Chen. 1995. "Kuerde gongrendang wenti ji qi dui Tuerqi neiwai zhengce de yingxiang (The Question of the Kurdish Workers Party and Its Impact on Turkey's Domestic and Foreign Policy)." Xiya Feizhou (West Asia and Africa) 4: 19-24.

Kumar Behera, Deepak. 1999. "Ethnic Identity and the Adjustment Pattern of BritishBorn Sikh Children in the United Kingdom." In Roots and Routes. Ethnicity and Migration in Global Perspective, edited by Shalva Weil: 65-84. Jerusalem:The Magnes Press.

Landau, Jacob. 1995. Pan-Turkism: From Irredentismto Cooperation. Bloomington: Indiana University Press.

Leonard, Peter. 20og. "Kazakh Uighurs Hold Mass Protest.” Associated Press 19 July.

Li, Yuanging. 199o. "Population Changes in the Xinjiang Uyghur Autonomous Region (1949-1984)." Central Asian Survey 9(1): 49-73.

Light, Nathan. 2008. Intimate Heritage, Creating Muqam Song in Xinjiang. Piscataway, NJ \& London: Transaction Publishers.

Millward, James A. 2007. Eurasian crossroads, history of Xinjiang. New York: Columbia University Press.

Millward, James A. 2009. "Introduction: Does the 2009 Urumchi Violence Mark a Turning Point?" Central Asian Survey 28(4): 347-6o. 
Radio Free Asia. 2017a. "China Bans Uyghur Language in Schools in Key Xinjiang Prefecture." (July 28). Available at: <http://www.rfa.org/english/news/uyghur/lan guage-07282017143037.html>.

Radio Free Asia. 2017b. "Chinese Police Order Xinjiang's Muslims to Hand in All Copies of the Quran.” (September 27). Available at: <http://www.rfa.org/english/news/uy ghur/chinese-police-order-xinjiangs-muslims-to-hand-in-all-copies-of-the-qurano9272017113203.html>.

Shichor, Yitzhak. 2003. "Virtual Transnationalism: Uyghur Communities in Europe and the Quest for Eastern Turkestan Independence." In Muslim Networks and Transnational Communities in and across Europe, edited by Stefano Allievi and Jørgen S. Nielsen: $281-311$. Leiden, Boston: Brill.

Shichor, Yitzhak. 2007. "Limping on Two Legs: Uyghur Diaspora Organizations and the Prospects for Eastern Turkestan Independence." Central Asia and the Caucasus 6(48): 117-125.

Si Liang. 2000. "China and Turkey Made Joint Efforts to Curb 'Xinjiang Independence' Activities," Zhongxun She News Agency (Hong Kong), in Guangzhou Ribao (Gauangzhou Daily), 21 April.

Troop, Stanley. 2004. “The Demographic of Xinjiang." In Xinjiang: China's Muslim Borderland, edited by Federick Starr, 241-263. Armonk, New York: M.E. Sharpe.

Tyler, Christian. 2003. Wild West China: The Taming of Xinjiang. London: John Murray. Valtonen, Kathleen. 1998. "Resettlement of Middle Eastern Refugees in Finland: The Elusiveness of Integration." Journal of Refugee Studies 11(1): 38-6o.

Xiang, Yi. 2019. "Xinjiang: The Largest Outdoor Prison in the World." March 29. Available at: <https://bitterwinter.org/xinjiang-the-largest-outdoor-prison-in-the-world $>$. 